\title{
FATORES DETERMINANTES DO AMBIENTE CULTURAL E SOCIAL NO ENSINO DE ADMINISTRAÇÃO NA REGIÃO NORDESTE DO BRASIL
}

\author{
DETERMINING FACTORS OF THE CULTURAL AND SOCIAL ENVIRONMENT IN \\ MANAGEMENT EDUCATION IN THE NORTHEAST REGION OF BRAZIL
}

Recebido em 30.11.2018. Aprovado em 15.05.2019 Avaliado pelo sistema double blind review

\section{Thales Batista de Lima} DOI: https://doi.org/10.12712/rpca.v13i2.27444

thalesufpb@gmail.com

Universidade Federal da Paraíba - João Pessoa/Paraíba, Brasil

https://orcid.org/0000-0002-2338-0451

\section{Anielson Barbosa da Silva}

anielson@uol.com.br

Programa de Pós-Graduação em Administração, Universidade Federal da Paraíba - João Pessoa/Paraíba, Brasil https://orcid.org/0000-0002-6549-9733

\section{Resumo}

Este artigo objetiva identificar fatores determinantes do ambiente cultural e social no ensino de Administração na percepção de docentes que participaram da criação dos cursos de graduação em Administração no Nordeste brasileiro. Para alcançar o objetivo, foi realizada uma pesquisa qualitativa a partir de entrevistas com professores que participaram da criação de cursos em universidades públicas. Os resultados revelaram que a regulamentação da profissão, o contexto da região, os desafios da formação do administrador no Nordeste e a identidade do ensino em Administração se configuram como fatores determinantes que impactaram no ensino de administração na região.

Palavras-chave: Ambiente cultural e social. Docentes. Nordeste. Ensino. Administração.

\begin{abstract}
This article aims to identify determinants of the cultural and social environment in management education according to the professor's perception who participated in the creation of undergraduate courses in management in the Northeast of Brazil. To reach the objective, a qualitative research was conducted from interviews with professors who participated in the creation of the courses in public universities. The results showed that the regulation of the profession, the context of the region, the challenges of administrator training in the Northeast and the identity of teaching in management are the determining factors that have an impact on the teaching of management in the region.
\end{abstract}

Keywords: Cultural and Social Environment. Teachers. Northeast. Teaching. Management. 


\section{Introdução}

A história do ensino de Administração revela um ambiente de aprendizagem dinâmico em função de fatores estruturais e institucionais que ajudam a entender o processo de ensino-aprendizagem do curso. Os agentes públicos envolvidos na formação são os responsáveis pela institucionalização de processos de ensino que possibilitam uma formação qualificada do aluno e condizente com seu ambiente de aprendizagem (LIMA; SILVA, 2017b).

Conhecer às peculiaridades do ambiente a partir de uma perspectiva regional, e perceber até que ponto o ensino em Administração no Brasil tem favorecido uma interação entre teoria e prática no processo de aprendizagem do estudando, com o objetivo de promover uma maior integração entre a formação e a atuação profissional a partir de uma perspectiva analítica e substancial incorporando o contexto institucional. A formação do administrador deve enfatizar uma maior ênfase em análises sistemáticas e críticas da realidade, o que é preciso promover uma formação capaz de promover uma práxis emancipatória na construção do conhecimento, contribuindo para reduzir a visão generalista e monopolística do administrador (BURGOYNE; REYNOLDS, 1997; MISOCZKY, 2006; SILVA; SILVA; FREITAS, 2013).

De acordo com Paes de Paula (2012), incorporar a emancipação no processo de formação pode ser capaz de transformar o indivíduo em um sujeito mais crítico em seu contexto social. Muzzio e Castro (2008) atentam para a relevância de conhecer o Brasil a partir de suas diferentes regiões culturais e $\mathrm{o}$ reconhecimento desta distinção para as organizações brasileiras. Vale a pena frisar que esses autores entendem região cultural como um espaço territorial, não necessariamente idêntico a fronteiras oficiais, onde os traços culturais (tais como, valores, atitudes e comportamento de seus membros) são reconhecidamente homogêneos entre si e heterogêneos em relação à outras regiões. Há uma pluralidade cultural e cada indivíduo apresenta um conjunto de traços culturais. Assim, o ensino em Administração deveria incorporar uma perspectiva regional, compreendendo as delimitações oficiais de cada região do país para que o ensino tenha considerado as peculiaridades existentes nos Estados das regiões, que apresentam diferenças e similaridades, a partir da apreciação sobre o ambiente de aprendizagem.

Como afirma Muzzio (2010), é preciso avançar desde uma visão determinista para uma perspectiva relacional do espaço, uma vez que cada região recebe influências externas, ou seja, os sistemas operam dentro de uma simbiose entre o local e o global. Neste artigo, parte-se do pressuposto de que a formação com ênfase na região aproxima o aluno do seu campo organizacional, de forma que ele pode contribuir para a sua própria região por meio de uma formação mais apropriada à sua realidade contextual.

Assim, reforça-se que o trabalho apresenta peculiaridades do Nordeste exporão apresentar suas características distintas das demais regiões do país, defendendo, também, diferenças entre os próprios Estados que integram a região estudada. E, torna-se imprescindível a identificação de fatores associados ao ambiente de aprendizagem do aluno, uma vez que aspectos sociais e culturais influenciam o desenvolvimento do ensino de Administração na região.

Orientar o aluno sobre o ambiente social e cultural no qual ele se insere, relacionando-o à cultura regional, constitui-se em uma atividade relevante em qualquer formação profissional. $\mathrm{Na}$ Administração, por exemplo, conhecer as especificidades da gestão de um Estado específico e dos demais Estados da região, além de particularidades culturais e sociais, pode trazer implicações para as práticas de gestão mais efetivas, uma vez que existem hábitos, costumes e tradições que caracterizam um estilo brasileiro de administrar (FREITAS, 1991; PRATES; BARROS, 1997), que necessariamente não relega as práticas modernas de gestão em nível nacional ou internacional, mas as contextualiza a um ambiente da ação profissional mais específico, o que daria maior singularidade e aderência à formação acadêmica do administrador. 
No processo de ensino em Administração, pode-se considerar as peculiaridades do ambiente cultural e social de aprendizagem que impactam no processo de formação e, com isso, oportunizar o desenvolvimento profissional orientado também para o interesse social e que seja capaz de contribuir com o crescimento e a transformação organizacional e social de uma região.

Este artigo objetiva caracterizar os fatores determinantes do ambiente cultural e social do ensino de Administração na percepção de docentes que participaram da criação dos cursos de graduação em Administração no Nordeste brasileiro. A principal contribuição do artigo é recuperar historicamente aspectos sociais e culturais que foram determinantes na evolução do ensino na região e ajudarem a entender o seu desenvolvimento a partir de especificidades culturais e sociais que caracterizam singularidades da formação do administrador na região. Assim, o trabalho pode auxiliar os agentes envolvidos na formação de administradores a refletirem sobre ações pedagógicas a partir do contexto do aluno, em termos de inserção social e aspectos culturais que preponderam na região, para que ofereçam uma formação condizente com tal ambiente de aprendizagem do aluno. Isso possibilita ao discente desenvolver competências mais adequadas para sua atuação profissional, sobretudo, na própria região.

\section{Teoria Utilizada}

O ambiente cultural e social contribui no processo de ensino-aprendizagem, pois pode potencializar a articulação entre teoria e prática. Ao considerar os aspectos culturais e sociais em nível local, na formação de administradores, o processo de aprendizagem também acontece coletivamente, uma vez que as pessoas interagem por meio do convívio social em busca de uma vida equilibrada e significativa na comunidade. Logo, a cultura, em contraste com a natureza, é um universo dotado de multiplicidade de significados, constituído por meio das relações humanas (JARVIS, 2006). A aprendizagem é um processo por meio da qual o aluno internaliza a cultura a partir de elementos internos e externos, relevantes para a realidade social, que leva o indivíduo a perceber e experienciar o mundo social. O processo de socialização contribui para a aprendizagem quando é capaz de promover um processo de reflexão e mudança nas perspectivas de significado (MEZIROW, 2000), o que impacta no desenvolvimento moral e delimita formas idiossincráticas de enxergar a realidade.

Sob essa perspectiva, o ensino em Administração pode possibilitar uma maior interação social na relação entre alunos, como também entre alunos e professores no ambiente da sala de aula, e do aluno com o ambiente cultural e social, a partir da interação com representantes de associações, órgãos públicos, entidades sociais, conselhos, empresários e funcionários de organizações de diferentes portes, setores e áreas de atuação, visando favorecer um aprendizado teórico-prático ao aluno, auxiliá-lo na mediação com o seu contexto (LIMA; SILVA, 2017a; LIMA, 2011), como também auxiliar no desenvolvimento de um profissional capaz de impactar o desenvolvimento regional. Merriam e Bierema (2014) reforçam que a cultura envolve um conjunto de pressupostos compartilhados; porém, muitas vezes, desarticulados, e que permeiam o pensamento e a ação.

Merriam e Brockett (2007) também consideram que o ambiente social é mediado pelas características culturais do ambiente de ensino-aprendizagem, o que demanda a capacidade de reconhecer fatores de gênero, raça, etnia, entre outros, para identificar estratégias para ensinar aos alunos a partir do ambiente cultural e social local. Como ator determinante no processo de formação do administrador, o professor também possui traços culturais que impactam a maneira como realiza o seu trabalho, a sua forma de pensar e de agir, além da construção do conhecimento para difundi-lo em sala de aula por meio do ensino.

Já o currículo do curso apoia os processos formativos do trabalho universitário e que delimita os conhecimentos e habilidades que devem contribuir para os futuros profissionais e que deveriam estar alinhados ao contexto social do mundo do trabalho. Além disso, o mercado de trabalho, marco da influência externa, atua como definidor das expectativas de emprego, mas também determina as 
condições de acesso ao emprego e às necessidades de formação. Esses aspectos direcionam os interesses e as demandas dos estudantes (ZABALZA, 2004).

O ensino de Administração deveria considerar a análise do ambiente cultural e social, por meio da compreensão da dinâmica do mundo de trabalho, principalmente local, para a inserção regional de seus alunos em postos de trabalho condizentes com a formação profissional do administrador. No Nordeste, por exemplo, percebe-se uma predominância de empresas de pequeno porte, de natureza familiar, que geralmente não utilizam processos e práticas profissionais de gestão e cabe ao administrador contribuir para transformar esse contexto de modo que a profissionalização das empresas contribua para o desenvolvimento regional e por meio da atuação do administrador não apenas como agente de transformação organizacional, mas também como agente de transformação social.

Por outro lado, a dificuldade de inserção no campo específico de atuação do administrador leva muitos alunos e egressos de cursos de uma região a se submeterem a empregos em áreas e atividades diferentes do campo de atuação profissional de um administrador ou decidem se mudar para outras regiões pela escassez de postos de trabalho (LIMA, 2011).

O Nordeste, por exemplo, é uma região heterogênea, que possui diferentes setores (serviços, indústria, construção e comércio) que absorvem mão de obra, mas o nível de desenvolvimento em termos de gestão e de profissionalização não é homogêneo tanto entre empresas de um mesmo setor, quanto em empresas de setores diferentes. A região também é marcada pelo fenômeno de migração de retorno devido ao inchaço populacional de outras regiões, até mesmo por nordestinos, que no século passado migraram, essencialmente, para a região Sudeste em decorrência de fatores econômicos e políticos (POLARI, 2012).

Araújo (2004) argumenta que Estados como Piauí, Paraíba e Maranhão possuíam, em décadas passadas, condições sociais mais precárias em relação a outros Estados, o que fez levou a migração para a região Sudeste. Por outro lado, a criação de universidades contribuiu para a difusão de ensino e pesquisa, o que trouxe impactos positivos para o desenvolvimento da região. Assim, o crescimento das classes médias urbanas contribuiu para dinamizar o campo institucional, uma vez que o espaço de controle das 'velhas oligarquias', conforme alega a autora, abriu espaço para um novo contexto empresarial. A partir dos anos 1980, os empresários locais passaram a se articular com os empresários de porte nacional, que passaram a investir no Nordeste e que promoveram um movimento de regionalização do grande capital.

O processo de formação na área de Administração também deve possibilitar ao aluno compreender a dinâmica do contexto local e com isso torná-lo mais preparado não apenas tecnicamente, mas capaz de compreender a dinâmica cultural e social do contexto regional. Isso ajudaria o profissional a entender o dinamismo e a complexidade das mudanças necessárias na gestão de determinada empresa e o seu contexto com o propósito de contribuir para o desenvolvimento econômico e regional.

Segundo Lima e Silva (2015), considera-se que um profissional de Administração com uma formação mais alinhada aos seus aspectos regionais tem a possibilidade de atuar de maneira mais efetiva no entorno da sua região, fortalecendo até mesmo aspectos culturais, que podem se tornar obsoletas ao longo do tempo caso as práticas de gestão não contribuam para a preservação e renovação do ambiente institucional. No Nordeste, por exemplo, existem manifestações culturais dos festejos juninos (CARVALHO, 2011; SANTOS; FEITORA, 2015); o Carnaval em regiões de musicalidade particular como o axé, o frevo e maracatu (GAIÃO; LEÃO, 2013; NOGUEIRA, 2006; OLIVEIRA; OLIVEIRA, 2005), bem como a zabumba; a festa do Bumba-meu-boi (SANTOS; HELAL, 2017); a dança de coco; a capoeira; as festividades de cunho profano/religioso como Iemanjá, o candomblé e Padre Cícero; a literatura de cordel (VALE; BARBOSA; CARVALHO, 2013); e produtos artesanais de rede tecida, cerâmica e rendas (MORAES SOBRINHO; HELAL, 2017). Tais exemplos ajudam a entender porque é difícil estabelecer um perfil homogêneo do Nordeste diante de um ambiente cultural e social multifacetado, o que leva as instituições de ensino a refletirem sobre como incorporar essa diversidade na formação de administradores na região. 
Araújo (2004) classifica o Nordeste como uma região de vários nordestes e observa que, no cenário brasileiro, questões socioeconômicas já não são somente regionais, mas há um ambiente socioeconômico nacional regionalmente localizado. Logo, o ensino de Administração pode contribuir no resgate das características regionais como fonte de desenvolvimento econômico, ambiental, social e cultural. Além disso, ao possibilitar a aplicabilidade real de práticas organizacionais aos diferentes contextos sociais, pode-se fomentar a disseminação de um ensino regionalizado e capaz de promover uma maior integração teoria-prática.

Durante as décadas de 1940 e 1950, os cursos de Administração surgiram para suprir as demandas por uma gerência científica para a burocracia especializada requerida para o desenvolvimento do país (NICOLINI, 2003). No caso do Nordeste brasileiro, o ensino de graduação em Administração surgiu em 1959 na Universidade Federal da Bahia (RIBEIRO, 2011), com uma formação orientada para a Administração Pública. Entretanto, em 1931 foi criado um curso de Administração com ênfase em finanças no Estado da Bahia, mas foi substituído pelos cursos de ciências econômicas e contábeis no ano de 1945. Em 1959 foi criada a escola de Administração, antes mesmo da Universidade da Bahia passar a ser denominada de Universidade Federal da Bahia, o que ocorreu em 1965.

No período compreendido entre os anos 1940 a 1960 foi marcado pela proliferação de cursos específicos para Administração Pública que acompanhavam a diversificação de seu modus operandi, destacando-se no Nordeste as seguintes instituições públicas: Universidade Federal da Bahia (UFBA) em 1959, Universidade Federal de Pernambuco (UFPE) também em 1959, e a Universidade Estadual do Ceará (UECE) em 1961 (COELHO, 2006). Nessa época, surgiram várias escolas de Administração pelo Nordeste, tendência que foi potencializada pela abertura de novos cursos na década de 1970. Constatase que, nos Estados do Ceará e do Maranhão, o surgimento dos cursos de Administração ocorreu nas Universidades Estaduais, diferentemente dos outros Estados da região, onde tais cursos surgiram nas Universidades Federais.

Destaca-se que o ambiente de aprendizagem no período de 1960 e 1970, não era marcado por uma forte pressão social por emprego e as prioridades dos professores e alunos em relação ao estudo nem sempre estava ligado à vida profissional. Os cursos, por serem generalistas, permitiam aos estudantes adquirirem uma visão ampla de cunho ideológico/político e cultural. O número de alunos era menor. Logo, se tornava mais fácil a interação entre eles e os professores de outras áreas, passando mais tempo na universidade (nesta época, concebida mais nos moldes de faculdades) até para mobilizações estudantis (ZABALZA, 2004). Essa característica influencia particularmente na formação do administrador, uma vez que o conduz a uma consciência política e participativa.

Araújo (2004) relata que a partir dos anos de 1970, impulsionadas pelos incentivos fiscais, por investimentos de empresas estatais do porte da PETROBRÁS (na Bahia) e da Vale do Rio Doce (no Maranhão), complementados com créditos públicos (do Banco Nacional de Desenvolvimento - BNDES e Banco do Nordeste do Brasil - BNB, particularmente) e com recursos próprios de importantes empresas locais, nacionais e multinacionais, as atividades urbanas (e dentro delas, as atividades industriais) ampliaram a participação no ambiente econômico do Nordeste e passaram a comandar o crescimento da produção nessa região brasileira, rompendo a fraca dinâmica preexistente. Então, nas décadas seguintes de 1980 e 1990, o país vivencia reformulações na sua própria ideia de desenvolvimento, também influenciada pelo mercado externo, tornando-se um Estado mais regulador (COELHO, 2008).

Parte-se do pressuposto que a elaboração de projetos acadêmicos e institucionais também deve considerar as potencialidades de uma região para caracterizar a demanda e o perfil do profissional, e nesse processo é fundamental considerar o ambiente cultural e social, além de vislumbrar que aspectos cognitivos, comportamentais e demográficos auxiliam a compreender a natureza multifacetada e complexa do ambiente de aprendizagem da formação do administrador. 


\section{Procedimentos metodológicos}

O trabalho objetiva a caracterização de fatores determinantes do ambiente cultural e social na trajetória do ensino de Administração na percepção de docentes que participaram da criação dos cursos de graduação em Administração no Nordeste brasileiro. Assim, a pesquisa está balizada pelo paradigma interpretativista, que conforme Burrel e Morgan (1979), tenta entender e explicar o mundo social. Ou seja, para encontrar o significado de uma ação é necessário que se compreenda de um modo específico o que os sujeitos estão fazendo (MARRA; BRITO, 2011).

Dessa forma, o estudo tem uma abordagem qualitativa, na qual Creswell (2010) define como sendo um meio para explorar e compreender o significado que os indivíduos atribuem a um problema social ou humano. A abordagem qualitativa aproxima o pesquisador dos sujeitos pretendidos no intuito de entender como pode ser construída uma formação que leva em conta o ambiente de aprendizagem cultural e social.

Os sujeitos da pesquisa foram nove professores e para a coleta de dados optou-se pela entrevista utilizando um roteiro não estruturado. As entrevistas foram realizadas presencialmente com dois docentes e via Skype com os demais porque residiam em outros estados da região Nordeste. Conforme Braga e Gastaldo (2012), esta interação mediada tecnologicamente por meio de imagens e vozes dos docentes se torna uma excepcional possibilidade de interação e obtenção de dados na pesquisa empírica, pois se aproxima da situação social presencial.

O perfil dos entrevistados envolve cinco homens e quatro mulheres. À exceção de um, todos possuíam a titulação de Doutor. Em geral, todos tiveram experiência profissional em ambas as esferas privada e pública, além da acadêmica. Àqueles que vivenciaram mais fortemente a vida acadêmica, atuando na pósgraduação, também estabeleceram vínculos internos à instituição exercendo cargos administrativos. A maioria dos entrevistados já estava aposentado no momento da realização da pesquisa.

As entrevistas foram gravadas e transcritas na integra. O processo de análise de dados ocorreu após a codificação e categorização dos seus discursos. Os nomes dos docentes foram identificados por DI até DIX. Para a análise dos dados, foi utilizada a análise compreensiva e interpretativa dos dados proposta por Silva (2005). As categorias que emergiram da análise foram as seguintes: regulamentação da profissão; contexto da região; desafios da formação do administrador na região; e, identidade do ensino em Administração. Após a categorização, procurou-se analisar o significado dos discursos de cada categoria e sua articulação com a base teórica analisada.

\section{Apresentação e análise dos resultados}

A formação do administrador foi regulamentada na metade da década de 1960. Antes, a ciência da Administração era confundida com a ciência econômica (NICOLINI, 2000). Esse dispositivo legal previa que o acesso ao mercado de trabalho seria privativo dos portadores de títulos expedidos pela universidade e, posteriormente, dos vinculados ao Conselho (Federal ou Regional). A regulamentação da profissão do administrador ocorreu durante o governo militar e contribuiu para o crescimento dos cursos em função da obrigatoriedade do curso superior na área. Pode-se afirmar que a regulamentação da profissão foi o primeiro fator determinante do ambiente social e cultural que impactou no ensino de administração no Brasil. Por outro lado, destaca-se que o ambiente de aprendizagem do aluno não apresentava uma identidade própria, que também dificultou a atuação do conselho pelo fato de o curso já ter sido concebido de forma difusa, sem uma noção definida do que envolveria o ato de administrar, uma vez que esta área surge pela idealização de professores com formação em outras áreas do conhecimento (COELHO, 2006; LIMA, SILVA, 2015). 
Assim, não é tão fácil estabelecer os limites da atuação profissional do administrador, pois profissionais de outras áreas já atuavam onde, posteriormente, foram destinadas para o administrador determinadas atividades das organizações. Além disso, os professores, de modo geral, não percebem que ocorreram mudanças significativas na formação do administrador após a sua regulamentação, as quais repercutem em níveis regionais.

A regulamentação da profissão de administrador acontece dentro de um contexto cultural e social bem peculiar no país, que foi durante o regime militar. O relato do professor abaixo detalha a visão sobre tal regulamentação e sobre a fase de criação dos conselhos como forma de regular esse processo.

"Essa história de regulamentação rolou uns quatro anos no Congresso e no regime militar, quando estava um negócio fechado. Em 1965, o Seu Humberto de Alencar Castelo Branco colocou lá o chamegão, eu tinha na época os pareceres de como isso foi aprovado, de como surgiu o projeto. [...] Pela reserva de emprego, reserva de trabalho, então, regulamenta a profissão e só pode administrar quem tiver o diploma e todo mundo vai correr pra fazer o curso e foi o que aconteceu. A explosão nas duas décadas seguintes de curso de Administração veio por conta disso e, hoje, é um dos maiores cursos. Mas como é que brasileiro cai numa coisa dessas." (DV)

O discurso do entrevistado revela que a regulamentação aconteceu sem uma discussão e participação coletiva de agentes envolvidos no processo formativo do aluno de Administração, havendo interesses particulares que incitaram a sua pronta aprovação naquela época. Por conseguinte, criam-se os conselhos, que são criticados pelos professores por sua postura passiva na trajetória do crescimento de cursos frente ao contexto do administrador, tanto em termos nacionais como também nas peculiaridades das organizações em nível regional.

Desse modo, antes da profissão ser regulamentada, as pessoas que exerciam atividades relacionadas à atuação do administrador não tinham conhecimento científico da área, até porque até a década de 1970 eram raros os cursos existentes no Nordeste. Após sua regulamentação, o país foi avançando na criação dos cursos, mas no Nordeste isso não significou uma adesão massiva ao processo formativo, até pela fraca atuação de vários dos conselhos regionais. Esse contexto social impactou na forma como os indivíduos percebiam e avaliavam o curso de Administração.

Alguns entrevistados enfatizam que não houve mudanças derivadas da criação de Conselhos e, da regulamentação da profissão. Para outros entrevistados, até houve algumas mudanças, mas pouco representativas em relação à capacidade e responsabilidade dos conselhos, como ilustram os discursos abaixo:

\footnotetext{
“Tem aquelas brigas também de poder, de quem defende posições, onde muitas vezes, quem está no conselho tá mais preocupado na manutenção dele no Conselho do que na categoria. Eu já fiz parte do conselho, saí, voltei e saí de novo. Como estou aposentada, hoje eu não estou mais em canto nenhum. Mas eu acho que a dificuldade que o Conselho tem não é somente por inoperância ou má vontade, é pelas próprias condições do surgimento da profissão e essa dificuldade em definir e estabelecer parâmetros pra um administrador, não é? [...]. Eu acho que a atuação do Conselho ainda é fraca, mas é dificultada pela própria dificuldade histórica de você definir o campo de trabalho de Administração.” (DI)

"Não, não, não teve mudanças por conta de regulamentação da profissão. A única consequência dessa regulamentação foi a criação dos Conselhos, que são Conselhos classistas. Esses conselhos regionais nunca fizeram nada a não ser interesses corporativos, se metiam dentro da universidade pra dizer aqui tem que ser um administrador, pois só quem pode fazer isso é administrador." (DII)
}

Por outro lado, alguns professores enxergam que os Conselhos podem ajudar a mudar a configuração da profissão, inclusive atuando mais fortemente em parceria com a estrutura universitária no desenvolvimento de uma formação do aluno de Administração adequada ao seu ambiente de aprendizagem, sobretudo o local. Os Conselhos foram se regionalizando justamente para se aproximar mais da realidade contextual dos profissionais de Administração.

"O Conselho Regional e acho que o Federal também, tem sido muito forte aqui no Rio Grande do Norte, colabora muito com a universidade. A parceria, pelo que conheço do Conselho, desde o tempo da sua fundação, que começou aqui junto com o da Paraíba, e fizemos uma comissão de professores de Administração, que eu fiz parte, onde tinha mais três colegas, e a universidade fazia parte desse Conselho, colaborando para que esse Conselho fosse forte. Demos 
a força inicial e tivemos um relacionamento salutar. Tanto o Conselho ajuda a instituição acadêmica como também a universidade ajuda o Conselho. [...] O Conselho leva o crescimento dos profissionais e nós queremos isso, fazendo sempre parcerias. [...]" (DIII)

Percebe-se nos discursos que, enquanto alguns professores criticam a atuação dos conselhos, outros destacam a sua força e colaboração com a universidade. Isso revela que a atuação regional de cada conselho, quando envolve ações de integração com a universidade, pode ser mais efetiva em suas ações para fortalecer a formação do administrador. Constata-se que os Estados com os conselhos mais bem estruturados e organizados conseguem desenvolver parcerias com os cursos de Administração e, consequentemente, o aluno percebe oportunidades no entorno de seu ambiente de aprendizagem.

Os resultados ainda revelaram que a regulamentação da profissão desencadeou mudanças no ambiente social, influenciadas por fatores culturais, mas que impactam o delineamento da formação do administrador. $O$ discurso transcrito a seguir explicita a importância da criação de uma cultura de valorização do administrador, fortalecendo a identidade da profissão no meio social, o que conduz a mudanças na formação para situá-lo em seu contexto regional.

Essa identidade é um processo de construção de significados com base em atributos culturais interrelacionados que os indivíduos experienciam coletivamente (CASTELLS, 2008). Ou seja, os envolvidos com o ensino em Administração influenciam na construção da identidade profissional do administrador (OLIVEIRA, 2014). Quando o ensino é trabalhado de maneira regional, pode-se agregar mais à identidade, pois se assume que ela é construída pelas comunidades locais por meio da ação coletiva e também preservada por uma memória coletiva, constituída de fontes específicas de identidades.

\begin{abstract}
"Quando nós criamos a Academia Cearense de Administração, a nossa preocupação, e amanhã é a mesma, é criar essa cultura da importância do administrador, avançar para que a sociedade tenha conhecimento dos papéis que o administrador exerce, da importância dele e da necessidade desta formação. Então, são questões que ainda estão muito longe da gente ver respeitadas. Isso acontece com as outras profissões também, mas é que as outras são mais específicas, [...] Mas se você precisa de alguém para administrar alguma coisa sua, você normalmente não se preocupa tanto assim se o cara é administrador ou não. Não é assim? A gente tem que ter essa preocupação de criar essa cultura da importância do administrador para que as coisas funcionem de forma adequada." (DVIII)
\end{abstract}

Assim, a forma como o curso de Administração expandiu, sobretudo no Nordeste, é fragilizada pela própria concepção da profissão do administrador. Os resultados da pesquisa sugerem que o processo de expansão do curso no Brasil teve uma contribuição da regulamentação da profissional, mas tal expansão não levou em consideração as peculiaridades regionais e difundiu em todo o país uma noção business advinda da região Sudeste que, por sua vez, foi introduzida no país a partir de um modelo norteamericano funcionalista, distinta das peculiaridades da realidade contextual e organizacional do Brasil, em especial, da região Nordeste, como afirma o estudo de Lima e Silva (2015).

Basicamente, entende-se esse processo inserido na cultura local como uma prática de mimetismo à luz do entendimento abordado pela teoria institucional. DiMaggio e Powell (2007) afirmam que as organizações tendem a uma orientação de isomorfismo institucional, e não apenas a uma burocratização em virtude da competição no espaço de mercado como abordado por Weber na década de 1960. Ou seja, as organizações podem provir de um isomorfismo mimético, que resulta de respostas padrão à incerteza. Isso pode ser observado como um reflexo da forma como o curso de graduação em Administração se inseriu na região Nordeste.

Outro fator determinante do ambiente cultural e social da trajetória do ensino de Administração é o próprio contexto da região Nordeste, uma vez que desde o surgimento do curso na região, a inserção do profissional de Administração foi marcada pelo predomínio do Governo na oferta do serviço público. Em virtude de interesses políticos e da forte atuação reguladora do Governo, os cursos de Administração, inicialmente, focaram-se na administração pública, uma vez que o Governo empregava boa parte da população do Nordeste no intuito de burocratizar os serviços públicos. 
No contexto privado, a região praticamente foi formada por empresas de micro e pequeno porte, e basicamente de cunho familiar (OLIVEIRA; FORTE, 2014). No Nordeste, é possível visualizar que setores do mercado de trabalho têm crescido nas últimas décadas, tais como comércio, construção civil e serviços. Destaca-se também o elevado número de empregos no âmbito da Administração Pública.

Este panorama ajuda a situar melhor o ensino em Administração, reforçando a necessidade de uma formação em âmbito local para possibilitar um alcance efetivo no aprendizado do aluno. Deve-se refletir sobre o mercado de trabalho da região nordestina, considerando os principais setores que contribuem para a geração de emprego formal. Daí, pode-se verificar comparativamente entre o ano de 2000 e 2013 que os trabalhadores da região têm atuado em atividades que possivelmente se tornam mais viáveis em função das contingências ambientais.

É nesse sentido que o ensino em Administração pode ser modificado, a partir do que é percebido nas dimensões do ambiente de aprendizagem para uma formação mais alinhada ao seu campo de atuação para promover a própria região, até mesmo em setores que ainda não têm tido tanta propagação na região. Para um melhor entendimento, o quadro a seguir caracteriza o mercado de trabalho na região a partir de uma análise comparativa entre os anos de 2000 e 2013.

\begin{tabular}{|c|c|c|c|c|c|c|c|c|c|c|}
\hline $\begin{array}{c}\text { SETOR/ESTADOS } \\
\text { - VALOR EM \% } \\
2000 / 2013\end{array}$ & MA & PI & $\mathrm{CE}$ & $\mathbf{R N}$ & PB & PE & AL & SE & BA & $\begin{array}{l}\text { TOT } \\
\text { AL }\end{array}$ \\
\hline Extrativa Mineral & $\begin{array}{c}0,22 / \\
0,34\end{array}$ & $\begin{array}{c}0,68 / \\
0,2\end{array}$ & $\begin{array}{c}0,39 / \\
0,24\end{array}$ & $\begin{array}{c}1,51 / \\
1,82\end{array}$ & $\begin{array}{c}0,44 / \\
0,22\end{array}$ & $\begin{array}{c}0,16 / \\
0,16\end{array}$ & $\begin{array}{c}0,18 / \\
0,2\end{array}$ & $\begin{array}{c}0,62 / \\
1,13\end{array}$ & $\begin{array}{c}0,5 / \\
0,7\end{array}$ & $\begin{array}{c}0,46 / \\
0,5\end{array}$ \\
\hline $\begin{array}{ll}\text { Indústria } & \text { de } \\
\text { Transformação } & \end{array}$ & $\begin{array}{l}7,2 / \\
5,99\end{array}$ & $\begin{array}{c}8,32 / \\
6,6\end{array}$ & $\begin{array}{c}20,78 \\
/ \\
17,64\end{array}$ & $\begin{array}{c}12,92 \\
/ \\
10,84\end{array}$ & $\begin{array}{c}13,28 \\
/ \\
12,29\end{array}$ & $\begin{array}{c}14,62 \\
/ \\
13,64\end{array}$ & $\begin{array}{c}22,45 \\
/ \\
18,24\end{array}$ & $\begin{array}{c}10,83 \\
/ \\
11,62\end{array}$ & $\begin{array}{c}8,97 / \\
9,9\end{array}$ & $\begin{array}{r}13,38 / \\
12,25\end{array}$ \\
\hline $\begin{array}{l}\text { Serviços Industriais de } \\
\text { Utilidade Pública }\end{array}$ & $\begin{array}{l}1,63 / \\
0,77\end{array}$ & $\begin{array}{l}1,75 / \\
1,14\end{array}$ & $\begin{array}{c}0,94 / \\
0,52\end{array}$ & $\begin{array}{c}0,91 / \\
1,03\end{array}$ & $\begin{array}{l}1,94 / \\
1,16\end{array}$ & $\begin{array}{c}1,51 / \\
1,11\end{array}$ & $\begin{array}{c}1,03 / \\
1\end{array}$ & $\begin{array}{l}1,47 / \\
1,47\end{array}$ & $\begin{array}{c}1,31 / \\
0,96\end{array}$ & $\begin{array}{c}1,34 / \\
0,96\end{array}$ \\
\hline Construção Civil & $\begin{array}{c}5,89 / \\
8,08\end{array}$ & $\begin{array}{c}5,42 / \\
8,39\end{array}$ & $\begin{array}{c}4,01 / \\
5,66\end{array}$ & $\begin{array}{c}4,38 / \\
6,77\end{array}$ & $\begin{array}{r}3,85 / \\
7,13\end{array}$ & $\begin{array}{l}4,94 / \\
8,26\end{array}$ & $\begin{array}{r}3,73 / \\
6,53\end{array}$ & $\begin{array}{l}5,35 / \\
7,36\end{array}$ & $\begin{array}{l}5,2 / \\
7,41\end{array}$ & $\begin{array}{c}4,77 / \\
7,27\end{array}$ \\
\hline Comércio & $\begin{array}{c}15,16 \\
/ \\
19,8\end{array}$ & $\begin{array}{c}15,03 \\
/ \\
19,16\end{array}$ & $\begin{array}{c}13,49 \\
/ \\
17,38\end{array}$ & $\begin{array}{c}13,21 \\
/ \\
19,17\end{array}$ & $\begin{array}{l}10,8 / \\
15,28\end{array}$ & $\begin{array}{c}14,33 \\
/ \\
17,83\end{array}$ & $\begin{array}{c}11,82 \\
/ \\
17,63\end{array}$ & $\begin{array}{c}14,15 \\
/ \\
16,14\end{array}$ & $\begin{array}{c}16,58 / \\
19,26\end{array}$ & $\begin{array}{r}14,37 / \\
18,17\end{array}$ \\
\hline Serviços & $\begin{array}{c}25,38 \\
/ \\
25,85\end{array}$ & $\begin{array}{c}20,78 \\
/ \\
26,55\end{array}$ & $\begin{array}{c}27,75 \\
/ \\
30,41\end{array}$ & $\begin{array}{c}23,27 \\
/ \\
28,26\end{array}$ & $\begin{array}{c}20,93 \\
/ \\
22,97\end{array}$ & $\begin{array}{c}28,24 \\
/ \\
33,28\end{array}$ & $\begin{array}{c}20,44 \\
/ 24,0 \\
5\end{array}$ & $\begin{array}{c}25,59 \\
/ \\
30,62\end{array}$ & $\begin{array}{l}31,3 / \\
32,62\end{array}$ & $\begin{array}{r}26,91 / \\
29,94\end{array}$ \\
\hline Administração Pública & $\begin{array}{c}42,94 \\
/ \\
36,58\end{array}$ & $\begin{array}{c}46,47 \\
/ \\
35,95\end{array}$ & $\begin{array}{c}31,12 \\
/ \\
26,42\end{array}$ & $\begin{array}{c}38,87 \\
/ \\
29,64\end{array}$ & $\begin{array}{l}45,3 / \\
38,87\end{array}$ & $\begin{array}{c}31,31 \\
/ \\
23,18\end{array}$ & $\begin{array}{c}33,02 \\
/ \\
30,47\end{array}$ & $\begin{array}{l}38,4 / \\
28,58\end{array}$ & $\begin{array}{c}31,54 / \\
25,28\end{array}$ & $\begin{array}{l}34,88 / \\
28,25\end{array}$ \\
\hline $\begin{array}{l}\text { Agropecuária, Extração } \\
\text { Vegetal, Caça e PespÁl }\end{array}$ & $\begin{array}{l}1,57 / \\
2,59\end{array}$ & $\begin{array}{l}1,55 / \\
2,02\end{array}$ & $\begin{array}{l}1,51 / \\
1,73\end{array}$ & $\begin{array}{c}4,92 / \\
2,47\end{array}$ & $\begin{array}{c}3,47 / \\
2,07\end{array}$ & $\begin{array}{l}4,88 / \\
2,55\end{array}$ & $\begin{array}{c}7,34 / \\
1,88\end{array}$ & $\begin{array}{l}3,58 / \\
3,06\end{array}$ & $\begin{array}{l}4,6 / \\
3,86\end{array}$ & $\begin{array}{c}3,89 / \\
2,67\end{array}$ \\
\hline
\end{tabular}

Tabela 1: Mercado de Trabalho (formal) no Nordeste por setores em 2000 e 2013

Fonte: Adaptado dos dados da Relação Anual de Informações Sociais do Ministério do Trabalho e Emprego

Ressalte-se que as pessoas que atuam em empregos formais nos setores apresentados raramente têm formação de ensino superior, embora tenha ocorrido um aumento significativo e pessoas com esse perfil no período de 2000 a 2013 na maioria dos Estados, exceto na Paraíba, conforme descrito na tabela 2. Esses dados demonstram a relevância de refletir sobre o ensino superior, nesse caso em Administração, para oferecer uma formação que contemple as suas necessidades e desenvolva habilidades requeridas pelo seu campo de atuação. 


\begin{tabular}{c|c|c|c|c|c|c|c|c|c|c}
\hline \multicolumn{1}{c|}{ ESTADOS } & MA & PI & CE & RN & PB & PE & AL & SE & BA & TOTAL \\
\hline $\begin{array}{l}\text { - VALOR EM \% } \\
\text { Ensino Superior } \\
\text { Completo - 2000 }\end{array}$ & 9,43 & 6,74 & 10,38 & 11 & 25,32 & 11,4 & 8,98 & 12,84 & 10,04 & 11,5 \\
\hline $\begin{array}{l}\text { Ensino Superior } \\
\text { Completo - 2013 }\end{array}$ & 15,76 & 19,74 & 17,89 & 18,46 & 18,49 & 18,78 & 12,53 & 19,7 & 14,84 & 17,05 \\
\hline
\end{tabular}

Tabela 2: Formação de Ensino Superior no Mercado de Trabalho (formal) no Nordeste em 2000 e 2013 Fonte: Adaptado dos dados da Relação Anual de Informações Sociais do Ministério do Trabalho e Emprego

Os dados acima evidenciam o aumento da procura pela formação superior no Nordeste, possivelmente em decorrência de mudanças percebidas nas exigências profissionais do mercado de trabalho. No entanto, pode-se questionar a capacidade desta formação de proporcionar um conteúdo condizente com o seu ambiente de aprendizagem do aluno, ou seja, com o mundo do trabalho local.

A mão de obra dos formados em Administração era predominantemente absorvida pelo Estado, o que se reflete ainda hoje no interesse de muitos alunos pela opção da carreira pública quando são questionados pelos professores. O Estado é visto como o grande empregador da região, o que causa certa inércia de iniciativas particulares para o desenvolvimento. Os discursos a seguir ilustram este panorama, que impacta a formação do administrador:

"Eu acho que as organizações, principalmente naquela época, em 1970 e 1980, eram muito amadoras. Quando o curso de Administração surge a gente não tinha nenhuma história de grandes empresas locais. As que tinham eram familiares e nem eu via também o Estado criando tantas instituições para absorver aqueles profissionais. Mas talvez pela modernidade que se avinhava, o curso de Administração passava a ser visto como algo que seria muito interessante pra o desenvolvimento local e regional. Tanto que ele foi sendo criado em outras universidades do Estado porque foi se criando uma crença de que esse seria um campo fértil para a sociedade precisar desses profissionais. [...]Veja bem, eu nunca vi essa preocupação regional. [...] Na verdade, quando as empresas vieram pra cá por incentivos fiscais elas trazem seus grandes administradores. Nunca vem pra aproveitar o pessoal que está aqui. Mas também, como eu disse, havia certa ingenuidade de que o curso iria até transformar a realidade local. [...]A ideia era que se for criar empresas na região, a gente já teria essa mão-de-obra preparada. A gente ficou preparando a vida toda um ensino para grandes empresas virem pra aqui. Aí nem vieram essas monstras pra cá, essas grandes empresas, e nem preparamos bem porque não se apostou na formação do administrador que vai trabalhar no município ou Estado [...].” (DI)

"Esses alunos da região se formavam para encontrar trabalho no Governo, iam todos atrás do governo. E como o Governo funcionava ao Deus dará, nunca houve uma preocupação pela excelência nem dentro dos cursos e nem fora pelos governantes. Até porque fora o mercado que absorvia eram as instituições públicas aqui na região Nordeste. Essas instituições não forçavam o aluno a ter uma qualificação, o governo funcionava de qualquer jeito. O aluno formado em Administração entrava por apadrinhamento ou indicação de deputados mesmo para as secretarias do governo e ficava ali pro resto da vida e ninguém botava mesmo pra fora, ninguém exigia nada dele." (DII)

Uma análise dos discursos acima revela que os professores entrevistados consideram que do ponto de vista cultural e social, havia a expectativa de que o curso de Administração assumisse um lugar de destaque no desenvolvimento regional, mas as políticas públicas de incentivo à instalação de unidades fabris não fortaleceram esse argumento porque o foco dos cursos de administração era formar profissionais para grandes empresas, muito distante do contexto regional, resultando em um desarticulação do ensino de Administração na região com o seu ambiente social e cultural. Isso tornou o Estado um dos agentes centrais na inserção dos administradores, mas que não oferecia um espaço de atuação profissional porque a gestão pública não era qualificada. Na verdade, tal ambiente impactou em ofertar cursos na região mais voltados à Administração Pública.

Além disso, o foco em formar um administrador para atuar em grandes empresas não era condizente com o ambiente contextual da região nordeste, cuja economia era baseada em pequenas empresas dos vários setores da economia. Em termos de competitividade, são as outras regiões que assumem um 
protagonismo em termos de desenvolvimento regional. Logo, a percepção de alguns dos pesquisados é que se criou a imagem de que as pessoas da região são conformadas e que os alunos de Administração acabam por procurar a via do concurso público para obter um emprego estável. Isso reflete a imaturidade do aluno em um aprendizado de domínio instrumental (MEZIROW, 2000), até pela sua falta de vocação profissional na área, submetendo-se ao que mimeticamente é posto na lógica de mercado da região, que é o profissional da área de Administração buscar por um concurso público como sendo um caminho mais rápido e fácil para êxito profissional, como aborda Oliveira (2014).

Assim, a cultura de ficar esperando tudo é associada pela população a um certo complexo de inferioridade e o desejo de imitar outras regiões e organizações avaliadas como sendo referências para o desenvolvimento, conforme o seguinte discurso: "A gente tá numa região pobre que fica sempre olhando para os outros, a gente ainda continua com o complexo de inferioridade, muitos de nós ainda têm a ideia de escravo sobre os senhores de engenho e ficamos sempre querendo imitar os grandes." (DVII).

Para Penna (1992), a visão do Nordeste como uma região pobre e inferiorizada é uma perspectiva de base ideológica autoritário-conservadora, de cunho oligárquico, defendida por alguns autores como Gilberto Freyre e Djacir Menezes, que a concebem como uma região em crise, atribuindo-a a uma característica de atrasada. Enfatiza-se que a ideologia fundamenta as teorias e juízos de valor das pessoas, tornando-se o meio básico que propicia uma consciência ao ser humano (FAISSOL, 1994). Por isso, a difusão das ideologias negativas a respeito do Nordeste pode ser prejudicial na tentativa de interação com as demais regiões e na criação de oportunidades de mercado e de qualificação educacional, inclusive para os alunos de Administração, que podem ser agentes transformadores da região.

Assim, a ideia de simplesmente imitar os grandes, como dito por DVII, é vazia. A formação do aluno universitário em Administração para aperfeiçoar as formas organizacionais locais não é valorizada. Uma das falas abaixo mostra justamente as especificidades no campo organizacional, seja privado ou público, que requerem a atuação de um administrador qualificado adequadamente.

\footnotetext{
"Eu acho que há certo esgotamento de oferta de alunos de Administração. Nós temos muitas universidades formando administradores e você chega na empresa pra vender seu produto, no caso seus alunos. Qual é o diferencial deles pra os outros das outras universidades para que a empresa absorva os meus? Hoje, eu acho que a gente vive uma crise, ne? Primeiro porque a gente não tem tantas empresas, isso é um problema. Estamos formando alunos para empresas, mas quê empresas? Onde estão elas na região? Essa sagração da Administração de Empresas tem levado a essa crise. É preciso focar mais pra que o professor possa até chegar junto do mercado e apresentar seu alunado como diferenciado por ele estar mais por dentro do que ocorre na sua realidade regional. Eu não sei como é que a gente faria isso não com o perfil que acabamos criando nos cursos da região, em uma formação para empresas, onde esse modelo de empresa não tem aqui. A gente criou uma empresa dos livros adotados no ensino que não tem aí fora. É uma concorrência grande entre as universidades que vão botar seus alunos pra esse mercado que não tem pra todos.” (DI)

"Eles precisam estar atentos que são as pequenas e médias empresas que sustentam o país. São elas que atendem grande parte da população, que estão mais próxima aqui, que empregam. Até as grandes empresas aqui do Ceará, muitas vezes, tem as diretorias localizadas em São Paulo, e no Ceará é que fica só a parte, digamos assim, de trabalho. A parte de lógica, estratégia não fica aqui, vão para onde conseguem se relacionar com as demais também de grande porte, dialogar melhor com o Governo Federal, com o mercado internacional e etc.” (DVIII)
}

É preciso encontrar um diferencial na formação dada ao aluno de Administração para que ele consiga se inserir melhor no seu contexto. Por sua vez, isso requer uma diversificação na oferta das formas organizacionais, como afirmam Merriam e Bierema (2014) sobre a pluralidade cultural no campo organizacional, o que expande a visão gerencialista alimentada no ensino e que restringe a própria atuação profissional do aluno de Administração.

Tais diferenças culturais e sociais também podem estar relacionadas à localização das instituições de ensino, se na capital ou no interior. As políticas de interiorização abordadas anteriormente se destinavam à expansão universitária pelas cidades do interior da região. Britto e Boson (1968), desde a década de 1960, já argumentavam que a universidade deveria marchar para a regionalização do campus, pois o país já sinalizava para necessidades de desenvolvimento no interior. No entanto, isso exige da universidade 
uma ação estratégica que, por vezes, não está entre suas prioridades, sendo mais fácil copiar o que já está consolidado, constatado no discurso de DVII. Aliás, muitas das ações adotadas são mais de cunho político. O estudo de Nascimento (2013) revela justamente falhas de políticas públicas em projetos de interiorização, mostrando casos de implementação de um campus universitário em locais do interior do Nordeste via influências políticas, com falta de planejamento que resulta em falhas na execução de obras e conflitos na comunidade acadêmica. Além disso, é preciso oportunizar no ambiente de aprendizagem dos alunos, no interior, a atuação do administrador.

\begin{abstract}
"Sim, tem. Quanto mais longe da capital ou quanto mais nos Estados pobres eu acho que se torna mais difícil a realidade da gente, de administrador. Aí é que não tem emprego porque não tem empresa mesmo. Se eu foco num curso e não dê a chance pro aluno ver a possibilidade dele usar aquilo na prática, numa prática local e imediata, como ele abrir um negocinho dele ou dele melhorar o negócio pequeno da família, de nada adianta. Nessa parte da interdisciplinaridade, de disciplinas complementares, que a gente flexibilizou na formação do aluno pelos PPC, na grade curricular, é onde a gente poderia ter um grande ganho vendo essas diferenças regionais. Mas eu acho que a gente não tá aproveitando isso como a gente poderia aproveitar, sabe? A gente tá na visão de um negócio pasteurizado mesmo, de ser mais ou menos como todo mundo é e acabou-se. Porque isso dar trabalho. Ser diferente dar trabalho até pra que as pessoas te reconheçam por isso." (DVII)
\end{abstract}

Observa-se que os professores divergem entre si no que diz respeito às singularidades do contexto da região. Alguns apontam diferenças de desenvolvimento devido às articulações políticas históricas realizadas por alguns Estados, conforme evidencia Araújo (2004). Outros, como o professor entrevistado abaixo, revelam que a região foi desconfigurada por influências do campo organizacional das regiões Sul e Sudeste, que implantaram suas organizações no Nordeste sem nenhuma promoção do desenvolvimento local.

\begin{abstract}
"Agora aqui no Nordeste eu acho que não houve essa preocupação nessa aplicação com o contexto local, em trabalhar o ensino dentro dessa realidade daqui, que é uma realidade pobre que não exigia grandes conhecimentos de Administração, já que não existiam grandes siderúrgicas, grandes estaleiras, companhias petrolíferas, têxteis que tivessem umas características diferentes das que estavam no Sudeste, por exemplo. Então, a coisa foi generalizada nessa preocupação de exigir algo pra aqui para a região. Eu acho que por conta disso é que setores empresariais nitidamente locais, característicos da região mesmo, todos eles se acabaram. E o que está havendo aqui são transferências simplistas de empresas de outras regiões pra cá. A indústria canavieira, cizaleira, têxtil, coureiro-calçadista, algodoeira, acabaramse. Não houve essa preocupação não com elas para desenvolvê-las na região. Simplesmente trás empresas de fora. O que existe hoje são grandes empresas que vem do Sul e Sudeste que dominam, se transferindo pra cá com o produto já todo pronto e com mão de obra de fora. Até de outros países, como a Fiat agora recente que trouxe vários italianos pra trabalhar em Goiânia. Vem já tudo pronto de fora sem usar e se preocupar com características locais. [...] Toda aquela pujança algodoeira, do cizal, têxtil de Campina Grande acabou-se rapaz.” (DII)
\end{abstract}

Portanto, essas dificuldades, se contornadas, encontram caminhos positivos no ambiente de aprendizagem do aluno para que ele possa aliar em seu processo formativo os conhecimentos adquiridos em sala de aula com a prática profissional, se tornando um agente ativo de mudança dessa realidade. Alinhado ao contexto, o processo de formação do administrador na região caracteriza-se como um determinante do ambiente social e cultural, uma vez que como revelam os discursos dos professores, os alunos tinham restrito ao contexto empresarial prejudicando a sua formação acadêmica.

"A dificuldade que eu vejo é de chegar até eles, porque os empresários se acham tão importantes, que se só vão os alunos eles não conseguem normalmente entrar na empresa. Daí precisa do professor entrar em contato pra conseguir esse acesso. Depois desse contato do professor, eles recebem super bem, tem grande prazer de participar dessas visitas [...]." (DVII)

Os resultados indicam ainda que o docente exerce um papel determinante na formação do administrador, mas uma ação docente efetiva depende, por sua vez, da estrutura curricular e da interdisciplinaridade, conforme indicam as falas abaixo:

“Olhe, aí vou dizer uma coisa que não é só do ponto de vista de estrutura curricular e didático. É o seguinte, eu já vi em vários cursos quando fazia avaliação de curso, que é seminários semestrais de integração de disciplinas. O currículo, hoje, basicamente voltou a ser seriado, como a gente já conversou, e eu fiz um trabalho aqui [...] que tem um seminário semestral, onde as disciplinas do semestre, que é tudo certinho com aquelas mesmas cinco disciplinas por semestre, onde 
elas se organizam para integrar um seminário no final do período que integra o assunto entre elas e com a localidade. Tem um tema problematizante que é colocado para os alunos nesse seminário e os alunos tem a oportunidade de estudar um aspecto que permeia nas cinco disciplinas. Não vê o problema como algo isolado de uma disciplina. E acho que poderia ter até integração entre turmas nisso aí com outros seminários. [...] Então, veja que não é qualquer trabalhinho besta fragmentado não. É um programa integrado, valorizado pela escola, sabe?” (DV)

Nessa fala, a experiência relatada pelo docente sinaliza a possibilidade de vivenciar a interdisciplinaridade no curso a partir de uma problematização a ser estudada pelos alunos em seu contexto local. O projeto pedagógico integra as disciplinas, dialogando entre si e com os problemas locais. Contudo, como o corpo docente é visto como individualista e não há mecanismos de fiscalização e estímulo a alterações no comportamento do docente para um maior envolvimento com os desafios do ensino em Administração, o cenário de mudança é dificultado. No entanto, a integração das disciplinas de um período letivo por meio de uma atividade única que abrangesse os conhecimentos das disciplinas seria realmente interessante, além de possibilitar uma formação regionalizada por meio da inserção do aluno de Administração em seu ambiente de aprendizagem local.

Diante desse panorama, o relato de um professor reflete que os desafios também são constantes pela dinamicidade que é o ensino de Administração. Logo, quando se soluciona um problema, outro desafio já surge. Porém, o professor reconhece que a intenção é de uma evolução continuada para o ensino em Administração e que, conforme a realidade contextual de cada curso, o avanço desse ensino precisa ser particularizado.

“Os desafios são enormes e acho que sempre vão existir porque Administração é uma coisa muito dinâmica, está sempre mudando e como as respostas são muito lentas, quando você consegue resolver alguma coisa já vão surgindo novos desafios. Agora comparando o ensino de Administração aqui na época que eu comecei com o que temos hoje, eu diria que houve um grande avanço. Acredito que daqui a 20 anos ou mais vai ser bem diferente, inclusive, não vai dar pra reconhecer nada com o de hoje." (DIV)

Alguns discursos reforçam que a valorização da formação em Administração é um reflexo do rigor destinado ao seu ensino. Para tanto, de acordo com a realidade do Nordeste, uma ação importante seria posicionar o aluno sobre sua realidade, inclusive a dos alunos do interior, resultado dos projetos de interiorização realizados pelo Governo. O discurso de DVII exprime o entendimento sobre a importância de despertar o aluno para o que está no seu entorno e, assim, tanto ele como a região possam crescer por meio da formação obtida em Administração na universidade pública. Dessa forma, trazer a prática para o ensino, mobilizando a pesquisa nesse elo, como alega Cunha (2012), pode ser um caminho favorável para uma formação mais regional.

Os professores alegam algumas alternativas desafiadoras para o ensino em Administração no Nordeste, em que uma delas é o empreendedorismo. "Isso também, de certo modo, é mais fácil, já que a empresa é menor, é mais fácil pra se adaptar a um sistema simples, mais rudimentar, mas é preciso mostrar os processos de empreendedorismo no curso de Administração aqui [...].” (DVII). Opinião compartilhada por outro professor: "Hoje, por exemplo, nós temos que pensar muito na questão do Empreendedorismo, muito mesmo. Temos que pensar também em termos de inovação, nós não podemos esquecer essa questão e nós temos que trazer para sala de aula, para as discussões com os alunos questões deste tipo. Não basta ele aprender somente a teoria, ele tem que também ver como é que essa teoria na prática vai funcionar ou deve funcionar." (DVIII).

Nesse sentido, as palavras microempresa, pequenas e médias empresas e cooperativas, utilizadas nos discursos dos professores pesquisados, definem o mercado da região Nordeste, além da esfera pública. Por isso, eles indicam o empreendedorismo para o ensino em Administração como o caminho para os alunos se empregarem e desenvolverem realmente a região. É possível que promovam uma profissionalização desses ramos de empresas, uma vez que são, por vezes, de cunho familiar amador e precário em termos de conhecimentos e competências em gestão. Nesse sentido, o ambiente social e 
cultural impacta diretamente nas perspectivas e tendências de um ensino de Administração mais efetivo na região Nordeste.

Em contrapartida, um dos professores questiona que ainda não há um dispositivo de acompanhamento na região que seja capaz de identificar se os alunos que procuraram empreender na região conseguiram realmente desenvolvê-la. É mais outro desafio para potencializar uma perspectiva singular para o ensino em Administração na região.

\begin{abstract}
"Sendo que nós nunca tivemos uma análise se os formados dão certo mesmo como empreendedores. Nós sabemos pela conversa do dia a dia, no informal, numa pesquisa anedótica, enfim, faltam dados porque infelizmente quando os alunos saem, se formam, nós perdemos o contato com eles. Nunca foi feita uma pesquisa empírica para detectar o impacto do ensino voltado ao empreendedorismo na vida profissional dessas pessoas. É uma coisa que precisa ser feita ainda. Pelo menos, isso é algo que fizemos e, quem sabe, eles desenvolvam aí a região, mas, além disso, nós não temos mais nenhum outro projeto com tal intenção." (DIV)
\end{abstract}

Por conseguinte, diversos professores defendem uma formação mais regional, sem que se perca a visão holística do que ocorre no cenário nacional e internacional no que diz respeito ao campo organizacional. Não é o conhecimento da ciência de Administração que será regionalizado, mas a aplicabilidade da teoria que será contextualizada, alinhando as problemáticas sociais do local à realidade organizacional da região. É tanto que os professores enfatizam a importância da pesquisa nesse elo entre teoria e prática, configurada no ambiente de aprendizagem do aluno.

Ou seja, a formação em termos regionais preza pelos princípios universais da Administração, mas os aplica localmente com a autonomia de analisar a sua contribuição para o desenvolvimento da região frente às suas particularidades. Podem-se reforçar certas teorias existentes ou contestá-las sobre a prática local, na qual os alunos poderiam renovar os conceitos vinculados com a experiência vivida a partir de uma relação entre a pesquisa e o ensino.

O último determinante cultural e social revelado pela análise dos dados se refere a identidade do ensino em Administração. Um dos professores entrevistados alega que é preciso apresentar uma identidade consistente do curso para os agentes externos, pois a comunidade ainda hoje não reconhece qual é a função de um administrador:

\footnotetext{
"Eu acho é que a gente ainda é tão pobre que não tem nem essa identidade. Eu não digo nem a gente da universidade, eu digo a comunidade em si. A comunidade mesmo não sabe o que é bem um administrador, quais seriam suas competências e o que ele poderia ajudar na sociedade. Eu acho que a comunidade sabe de outras profissões como o dentista, o médico, o engenheiro. A gente tem muito o que trabalhar para construir essa identidade, não interna. Acredito que dentro a gente sabe até o que é, mas é para comunidade em geral. Eu tô vendo de uma visão de fora pra dentro. Qual é realmente a utilidade do administrador para a nossa sociedade? Eu acho que a sociedade não reconhece isso, [...] Essa mudança eu acho que só vai acontecer quando a gente conseguir melhorar o nosso profissional, melhorar a nossa penetração, melhorar a nossa influência nesse mercado. [...] A partir do momento em que pessoas de destaque são administradores, vai conseguindo no senso comum criar essa identidade, a importância desse profissional.” (DVII)
}

O processo de construção de uma identidade transparente à sociedade demanda uma mudança mais profunda, envolvendo os empresários, os agentes públicos e os professores das universidades. Isso requer uma transformação na cultura, o que demanda a necessidade de um trabalho na formação do aluno que o conduza a uma transformação do horizonte de significado por meio do processo de aprendizagem. Assim, a cultura é construída por meio das relações humanas com sua multiplicidade de significados que permeiam o pensamento e a ação (JARVIS, 2006; MERRIAM; BIEREMA, 2014). Além disso, a transformação também demanda uma maior conscientização dos empresários a partir de um conhecimento apropriado sobre o profissional de Administração correspondente aos seus objetivos para a organização. Isso se encontra ilustrado no discurso abaixo:

"A identidade da gente está bem fraca, mas não sei se isso vai melhorar porque mudança de cabeça, de formação, de cultura é muito lenta. Estamos caminhando, ne? Os professores têm que mudar, mas também os empresários tềm que sentir necessidade da gente, de administradores em suas empresas. Eles têm que mostrar qual profissional eles querem 
porque nem eles mesmo, muitas vezes, não sabem o que querem. Eles não sabem nem o que estão avaliando, às vezes, nos candidatos." (DVI)

Palavras como blefe, tênue e vaga caracterizam a identidade do ensino em Administração, essencialmente, na região Nordeste segundo a percepção do entrevistado. Assim, essa caracterização realizada pelos professores entrevistados acerca do ensino em Administração converge com o entendimento de Alcadipani et al (2012) e Rosa e Alcadipani (2013) quando afirmam que o ensino em Administração do país carece de uma consciência crítica, refletindo na ausência de uma identidade autêntica e híbrida. Os professores afirmam que a identidade pode ser fortalecida quando há conexão com as práticas diárias no entorno da formação do aluno. Contudo, na região estudada, o aluno costumeiramente decide pelo curso por considerá-lo fácil, como já foi descrita por DVI, o que prejudica a construção de uma identidade. Aliás, esse prejuízo já é decorrente da fragilidade do próprio curso.

\begin{abstract}
"Eu acho que é um blefe, sabe? A gente não forma porque o bom aluno que a gente forma, na verdade, ele se forma mais do que o curso. O curso, de repente, pode dar pra ele uma certa sinalização de autores e de como estudar, mas ele só vai se tornar muito bom a partir de sua vivência. O que faz um bom administrador não é o conjunto de informações que ele recebeu em seus estudos, mas são as práticas no dia a dia, as decisões que ele vai tomar. E isso a gente não faz, não prepara o cara para ele decidir, isso tá perdido aqui." (DIII)

"É um curso com uma identidade muito tênue, muito vaga, sem muita identidade mesmo. A maioria dos alunos que faz Administração não sabe o que é o curso, eles não sabem o que querem, né? Então, é um curso que atrai muito este perfil de aluno e isso atrapalha. Aqui no Nordeste ele faz o curso de Administração porque é fácil de entrar e prejudica na identidade do curso. Esses anos todos a gente vem lutando, mas não conseguimos ainda criar essa identidade por conta da fragilidade do próprio curso.” (DVIII)
\end{abstract}

Outros professores reforçam tal fragilidade ao comentar que o curso preza pela retórica e pragmatismo, apenas replicando modelos. Para a região, é salutar uma identidade diferenciada, inclusive, dependendo da localidade, remetendo à questão do curso se situar na capital ou no interior, por exemplo. Isso implica no argumento de Araújo (2004) a respeito de ter vários nordestes, o que significa que características do ambiente social e cultural influenciam na definição de uma identidade.

“O nosso curso sempre foi muito de retórica, muito distante. [...] eu não fui preparada para ser administradora. Eu me preparei pra ser uma curiosa de Administração. Fui teórica de Administração, mas para ser uma administradora eu não fui preparada como aluna. Como professora eu percebi que esse viés permanecia no curso porque como a maioria dos professores não tem a prática não podiam falar de algo que desconheciam. O curso prepara o aluno pra ele reaplicar modelos. É a fisionomia do nosso curso de Administração, que pode ter alguma validade, mas não sei até quando.” (DI)

A formação de uma identidade para o ensino em Administração demanda esforços de agentes envolvidos no ambiente de aprendizagem, seja interno (por exemplo, gestores universitários, professores e alunos), seja externo (os empresários, governo e a comunidade), com o objetivo de potencializar a integração entre as universidades e o ambiente cultural e social da atuação do administrador no contexto regional, na qual pode ampliar as expectativas de atuação profissional e fortalecer o ensino de administração alinhado ao interesse público e integrado à sociedade.

Tomando como referência o processo de análise dos discursos dos docentes sobre o desenvolvimento cultural e social do ambiente de aprendizagem do ensino em Administração na região Nordeste, foram identificados alguns determinantes que subsidiam a compreensão de um processo formativo para $\mathrm{O}$ administrador mais contextualizado. 
Quadro 1: Fatores Determinantes do ambiente Cultural e Social no ensino de Administração no Nordeste brasileiro

\begin{tabular}{|c|c|}
\hline DETERMINANTES & O QUE REVELOU O ESTUDO? \\
\hline $\begin{array}{c}\text { Regulamentação da } \\
\text { profissão }\end{array}$ & $\begin{array}{l}\text { - A regulamentação da profissão do administrador ocorreu durante o governo militar e contribuiu } \\
\text { para o crescimento dos cursos em função da obrigatoriedade do curso superior na área. } \\
\text { - O ambiente de aprendizagem do aluno não apresentava uma identidade própria, que também } \\
\text { dificultou a atuação dos conselhos. } \\
\text { - A regulamentação aconteceu sem uma discussão e participação coletiva de agentes envolvidos } \\
\text { no processo formativo do aluno de Administração. } \\
\text { - Os professores criticaram os conselhos por sua postura passiva na trajetória do crescimento de } \\
\text { cursos frente ao contexto do administrador, tanto em nível nacional, como também nas } \\
\text { peculiaridades das organizações em nível regional. } \\
\text { - A forma como o curso de Administração expandiu, sobretudo no Nordeste, foi fragilizada pela } \\
\text { própria concepção da profissão do administrador, cuja atuação dos conselhos foi limitada mesmo } \\
\text { após sua regulamentação. }\end{array}$ \\
\hline Contexto da região & $\begin{array}{l}\text { - Desde o surgimento do curso na região, a inserção do profissional de Administração foi marcada } \\
\text { pelo predomínio do Governo na oferta do serviço público. } \\
\text { - A mão de obra dos formados em Administração era predominantemente absorvida pelo Estado, } \\
\text { o que se reflete ainda hoje no interesse de muitos alunos pela opção da carreira pública quando } \\
\text { são questionados pelos professores. } \\
\text { - O Estado foi um dos agentes centrais na inserção dos administradores, mas não oferecia um } \\
\text { espaço de atuação profissional porque a gestão pública não era qualificada. } \\
\text { - Do ponto de vista cultural e social, havia a expectativa de que o curso de Administração } \\
\text { assumisse um lugar de destaque no desenvolvimento regional, mas as políticas públicas de } \\
\text { incentivo à instalação de unidades fabris não fortaleceram esse argumento porque o foco dos } \\
\text { cursos de administração passou a ser a formação de profissionais para grandes empresas. } \\
\text { - O foco em formar um administrador para atuar em grandes empresas não era condizente com } \\
\text { o ambiente contextual da região nordeste, cuja economia era baseada em pequenas empresas de } \\
\text { vários setores da economia. }\end{array}$ \\
\hline $\begin{array}{c}\text { Formação do } \\
\text { Administrador na } \\
\text { região }\end{array}$ & $\begin{array}{l}\text { - Os alunos tinham acesso restrito ao contexto empresarial prejudicando a sua formação } \\
\text { acadêmica. } \\
\text { - Os docentes exercem um papel determinante na formação do administrador, mas uma ação } \\
\text { docente efetiva depende, por sua vez, da estrutura curricular e da interdisciplinaridade. } \\
\text { - A interdisciplinaridade no curso era institucionalizada a partir de uma problematização a ser } \\
\text { estudada pelos alunos em seu contexto local. } \\
\text { - O empreendedorismo era uma alternativa para o ensino em Administração como o caminho } \\
\text { para a empregabilidade dos e o desenvolvimento da região. } \\
\text { - Uma formação mais regional não implica em abandonar a visão de totalidade. Não é o } \\
\text { conhecimento da ciência de Administração que seria regionalizado, mas a aplicabilidade da teoria } \\
\text { contextualizada e alinhada às problemáticas sociais do local à realidade organizacional da região. }\end{array}$ \\
\hline $\begin{array}{l}\text { Identidade do ensino } \\
\text { em Administração }\end{array}$ & $\begin{array}{l}\text { - Necessidade de criar uma identidade consistente do curso para os agentes externos, pois a } \\
\text { comunidade ainda hoje não reconhece qual é a função de um administrador. } \\
\text { - O processo de construção de uma identidade transparente à sociedade demanda uma mudança } \\
\text { mais profunda, envolvendo os empresários, os agentes públicos e os professores das } \\
\text { universidades. } \\
\text { - A transformação na cultura demanda a necessidade de um trabalho na formação do aluno que } \\
\text { o conduza a uma transformação do horizonte de significado por meio do processo de } \\
\text { aprendizagem. } \\
\text { - A transformação também demanda uma maior conscientização dos empresários a partir de um } \\
\text { conhecimento apropriado sobre o profissional de Administração correspondente aos seus } \\
\text { objetivos para a organização. } \\
\text { - A identidade pode ser fortalecida quando há conexão com as práticas diárias no entorno da } \\
\text { formação do aluno. } \\
\text { - O curso preza pela retórica e pragmatismo, apenas replicando modelos. Para a região, é salutar } \\
\text { uma identidade diferenciada, inclusive, dependendo da localidade, remetendo à questão do curso } \\
\text { se situar na capital ou no interior. } \\
\text { - Potencializar a integração entre as universidades e o ambiente cultural e social da atuação do } \\
\text { administrador no contexto regional pode ampliar as expectativas de atuação profissional e } \\
\text { fortalecer o ensino de administração alinhado ao interesse público e integrado à sociedade. }\end{array}$ \\
\hline
\end{tabular}

Fonte: Elaborado pelos autores, 2018. 
Este quadro caracteriza os principais fatores determinantes a partir de reflexões sobre os discursos revelados pelos docentes participantes da pesquisa. Os resultados indicam que esses determinantes atuaram tanto de forma positiva, potencializando o papel do ambiente cultural e social no ensino de administração na região Nordeste, como também indicam aspectos que limitaram o desenvolvimento de uma formação que incorporasse elementos da cultura e da sociedade nordestina na formação e atuação do administrador.

\section{Considerações finais}

A identificação de fatores determinantes do ambiente cultural e social do ensino de Administração no Nordeste brasileiro é a principal contribuição deste artigo na tentativa de suscitar uma reflexão sobre a importância da formação do administrador no desenvolvimento regional. $\mathrm{O}$ ensino de administração no Nordeste teve uma trajetória de inserção balizada por uma perspectiva institucional a partir de uma lógica mimética, replicando estruturas curriculares de outras regiões do brasil, o que de fato acontece ainda hoje. Assim, este ensino é impactado pelos desdobramentos que ocorrem, historicamente, no meio social e cultural do qual se insere o aluno de Administração.

A regulamentação da profissão foi um dos determinantes que exerceu um papel importante na expansão dos cursos, mas os docentes que acompanharam o processo de criação dos cursos no Nordeste que participaram deste estudo destacaram que esse aporte não possibilitou uma formação mais adequada do administrador ao considerar os aspectos contextuais da região.

Uma das reflexões deste estudo envolve a necessidade de formar administradores com um pensamento mais analítico sobre a região para se tornarem agentes de transformação social. É preciso analisar como operacionalizar um ensino, capaz de inserir o aluno em seu ambiente de aprendizagem e ampliando sua visão sobre a Administração, superando a noção for business que prevalece no mercado. Para isso, há um trabalho profundo a ser realizado pelos agentes envolvidos com a educação em Administração para estimular um perfil mais vocacionado de seus alunos. Isso perpassa também pelo compromisso do professor em exercer a sua vocação para a docência, atualizando a sua formação pedagógica e buscando alternativas para melhorar a interação e a aproximação com os diversos segmentos empresariais.

Em síntese, a vocação pela profissão caminha pelo aprofundamento de sua identidade, e no Nordeste o ambiente social e cultural tem revelado aos cursos de Administração que as atividades relacionadas ao empreendedorismo em setores comerciais e de serviços, de cunho familiar e em pequeno e médio porte pode ser o percurso a trilhar nessa construção identitária.

Ademais, o contexto do funcionalismo público também tem evidenciado como um retorno ao seu fortalecimento na região, assim como organizações do ramo turístico devido aos fatores históricos e climáticos presentes na região, como também as singularidades gastronômicas e belezas naturais. Isso faz repensar o papel interdisciplinar da educação em Administração, valorizando atratividades regionais que podem ser melhores investidas e aplicadas por intermédio de profissionais que tenham obtido uma qualificação mais próxima de seu ambiente de aprendizagem social e cultural.

Portanto, essa reflexão sobre fatores determinantes do ambiente social e cultural que impactam no ensino de Administração no Nordeste pode contribuir para uma reflexão sobre a formação do administrador a partir da compreensão do ambiente de aprendizagem para aproximar o aluno ao contexto de atuação profissional. Para isso, pode-se identificar percursos formativos mais regionalizados que possibilitem ao aluno explorar as particularidades existentes na região, uma vez que o Nordeste é uma região distinta até entre seus próprios Estados. Esse estudo possibilita ampliar a visão de gestores acadêmicos para elaboração de propostas pedagógicas mais práticas ao contexto. 
Para uma agenda de pesquisa envolvendo futuros estudos, recomenda-se analisar as implicações de fatores culturais e sociais na formação de administradores em outras regiões do Brasil para verificar que características se assemelham com o ambiente do Nordeste, e se também há diferenças entre Estados como ocorre no Nordeste. Além disso, outros estudos poderiam avaliar as implicações de projetos pedagógicos mais orientados para o desenvolvimento local e seus impactos na empregabilidade dos egressos em nível local. Outras pesquisas podem abordar a relação entre formação e campo de atuação em cursos implantados em regiões do interior do Nordeste após a implantação da política de expansão empreendida pelo governo federal de expansão e interiorização das universidades públicas.

Espera-se que o estudo promova uma reflexão nos agentes públicos da educação superior e nos agentes empresariais responsáveis pela empregabilidade desses profissionais sobre o papel e a contribuição do administrador para a sociedade local.

\section{Referências}

ALCADIPANI, R.; KHAN, F. R.; GANTMAN, E.; NKOMO, S. Southern voices in management and organization knowledge. Organization (London), v. 19, p. 131-143, 2012.

ARAÚJO, T. B. Northeast, Northeasts: what northeast? Latin American Perspectives, v. 31, n. 2, p. 16-41, 2004.

BRAGA, A.; GASTALDO, É. Variações sobre o uso do Skeype na pesquisa empírica em comunicação: apontamentos metodológicos. Revista Contracampo, v. 24. n. 1. Niterói/RJ, 2012.

BRITTO, G.; BOSON M. A problemática universitária. Edição da UFMG. Minas Gerais/MG, 1968.

BURGOYNE, J.; REYNOLDS, M. (eds.) Management learning: integrating perspectives in theory and practice. London: Sage, 1997

BURREL, G.; MORGAN, G. Sociological Paradigms and Organizational Analysis: elements of sociology of corporate life. London, UK: Heinemann. Ashgate Publishing Company, 1979.

CARVALHO, K. D. (2011). Identidade, turismo e tradução cultural: análise da dinâmica dos eventos juninos no Maranhão. Rosa dos Ventos - Turismo e Hospitalidade, v. 3, n. 1, p. 62-72, 2011.

CASTELLS, M. O poder da identidade. Volume II. $6^{a}$ Edição. São Paulo: Editora Paz e Terra, 2008.

COELHO, Fernando de Souza. Uma radiografia do Ensino de Graduação em Administração Pública no Brasil (1995-2006). XXXII EnANPAD. Rio de Janeiro/RJ - 6 a 10 de Setembro 2008.

COELHO, F. S. Educação Superior, Formação de administradores e setor público: um estudo sobre o ensino de administração pública - em nível de graduação - no Brasil. Tese (Doutorado em Administração Pública e Governo). Escola de Administração de Empresas de São Paulo/FGV. 159 f. São Paulo/SP, 2006.

CRESWELL, J. W. W. Projeto de pesquisa: métodos qualitativo, quantitativo e misto. 2. ed. Porto Alegre: Bookman, 2010

DIMAGGIO, P.J.; POWELL, W. W. A gaiola de ferro revisitada: isomorfismo institucional e racionalidade coletiva nos campos organizacionais. In: Caldas, M. P.; Bertero, C. O. (Coord.) Teoria das organizações. São Paulo: Atlas, p. 117-142, 2007 
FAISSOL, S. O espaço, território, sociedade e desenvolvimento brasileiro. Rio de Janeiro: IBGE, 1994.

FREITAS, A. B. Traços brasileiros para uma análise organizacional. In: MOTTA, F. C. P.; FREITAS, M. E. de. Cultura organizacional: formação, tipologias e impactos. São Paulo: Makron Books, 1991.

Gaião, B. F. S.; Leão, A. L. M. S. (2013). Muitas festas numa só: a configuração do campo do carnaval do Recife. Organizações \& Sociedade, v. 20, n. 64, p. 131-144, 2013.

JARVIS, P. Towards a comprehensive theory of Human Learning: Lifelong learning and the learning society. Routledge, 2006.

LIMA, T. B. Estratégias de Ensino Balizadas pela Aprendizagem em Ação: Um Estudo de Caso no Curso de Graduação em Administração da Universidade Federal da Paraíba. 221f. (Dissertação de Mestrado em Administração) - Programa de Pós-Graduação em Administração, UFPB, João Pessoa PB, 2011.

LIMA, T. B.; SILVA, A. B. O Ambiente Histórico e Político do Ensino de Administração na Região Nordeste. V EnEPQ/ANPAD. Salvador/Bahia, 2015.

LIMA, T. B.; SILVA, A. B. Análisis de la difusión de estrategias de enseñanza en la acción en un curso de administración en Brasil. DESENVOLVE: Revista de Gestão do Unilasalle. Canoas, v. 6, n. 1, 2017a.

Lima, T. B.; Silva, A. B. O Ambiente Estrutural e Institucional do Ensino de Administração na Região Nordeste do Brasil. Administração: Ensino e Pesquisa, v. 18, n. 2, p. 231-269, 2017b.

MARRA, A. V.; BRITO, V. G. P. Construcionismo Social e Análise do Discurso: Uma Possibilidade Teórico-Metodológica. In: Encontro Anual da ANPAD, 35, Rio de Janeiro, 2010.

MERRIAM, S. B.; BIEREMA, L. L. Culture and Context, theory and practice in adult learning, chapter twelve. Adult Learning: linking theory and practice. 1 ed. San Francisco, Jossey-Bass, 2014.

MERRIAM, S. B.; BROCKETT, R. G. The profession and practice of adult learning: an introduction. San Francisco: Jossey-Bass, 2007.

MEZIROW, J. Learning to think like an adult: Core concepts of transformation theory. In:

MEZIROW, J. \& Associates (Eds). Learning as transformation: Critical perspectives on a theory in progress. San Francisco, CA. Jossey-Bass, 2000.

MISOCZKY, M. C. Sobre o centro, a crítica e a busca de liberdade na práxis acadêmica. Cadernos EBAPE.BR, v. IV, n. 3, out. 2006.

MINISTÉRIO DO TRABALHO E EMPREGO: Relação Anual de Informações Sociais. Fonte: http://portal.mte.gov.br/portal-mte/.

MORAES SOBRINHO, J.; HELAL, D. H. A Implementação de Políticas Públicas Voltadas a Atividades Artesanais: Análise do Programa de Artesanato da Paraíba. Organizações \& Sociedade, v. 24, n. 80, p. 115-134, 2017.

MUZZIO, H. Cultura organizacional na perspectiva cultural regional brasileira. Revista Brasileira de Gestão de Negócios. São Paulo, v. 12. n. 37. out/dez 2010.

MUZZIO, H.; CASTRO, D. J. Quantos Somos Nós? Uma Reflexão sobre os Brasis Culturais. V EnEO/ANPAD. Belo Horizonte/MG, 2008. 
NASCIMENTO, F. S. Expansão e Interiorização das Universidades Federais: uma análise do processo de implementação do Campus do Litoral Norte da Universidade Federal da paraíba. 147 f. (Dissertação de Mestrado em Administração) - Programa de Pós-Graduação em Administração, UFPB, João Pessoa - PB, 2013.

NICOLINI, A. Qual será o futuro das fábricas de administradores? RAE. Vol. 3. Nº 2. 2003.

NICOLINI, A. A graduação em administração no Brasil: Uma análise das políticas públicas. 109 f. (Dissertação de Mestrado em Administração Pública) Fundação Getúlio Vargas/Escola Brasileira de Administração Publica - Centro de formação acadêmica e pesquisa. Rio de Janeiro/RJ, 2000.

NOGUEIRA, R. M. Cultura ou mercadoria? Reflexões sobre o carnaval de Itabuna, Bahia. Caderno Virtual de Turismo, v. 6, n. 4, p. 55-61, 2006.

OLIVEIRA, A. L. Os reflexos da experiência formativa na vida profissional do administrador: uma investigação a partir da ótica de egressos da educação superior privada do sul de Minas Gerais. 165 f. Tese (Doutorado em Administração). PPGA/UFL (Universidade Federal de Lavras). Lavras - MG, 2014.

OLIVEIRA, M. F. S.; OLIVEIRA, O. (2005). Carnaval, turismo e trabalho informal na Bahia: tanto negócio e tanto negociante. Caderno Virtual de Turismo, 5(4), 15-25.

OLIVEIRA, O. V.; FORTE, S. H. A. C. Estratégias e Ferramentas Competitivas das MPEs da região Nordeste. Revista da Micro e Pequena Empresa da FACCAMP. v. 8. n. 2. Campo Limpo Paulista, 2014.

PAES DE PAULA, A. P. Estilhaços do real: o ensino da administração em uma perspectiva benjaminiana. Curitiba: Juruá, 2012.

PENNA, M. O que faz ser nordestino: identidades sociais, interesses e o "escândalo" Erundina. São Paulo: Cortez Editora, 1992.

POLARI, R. S. A Paraíba que podemos ser: da crítica à ação contra o atraso. João pessoa/PB: Editora da UFPB, 2012.

PRATES, M. A. S.; BARROS, B. T. O Estilo Brasileiro de Administrar. In: Motta, F. C. P.; Caldas, M. P. Cultura organizacional e cultura brasileira. São Paulo: Atlas, 1997, p. 55-69

RIBEIRO, Denise de Andrade. Trajetória institucional da universidade brasileira - a UFBA como reflexo e modelo. Tese (Doutorado em Administração) 294 f. Escola de administração. Universidade Federal da Bahia. Salvador: 2011.

ROSA, A. R.; ALCADIPANI, R. A terceira margem do rio dos estudos críticos sobre Administração e Organizações no Brasil: (re)pensando a crítica a partir do pós-colonialismo. RAM - Rev. Adm.

Mackenzie, v.14, n.6, ed. esp., p. 185-215, nov./dez 2013.

SANTOS, E. C. D.; HELAL, D. H. Práticas de Trabalho da Cultura Popular no Agreste de Pernambuco: Entre o Moderno e o Tradicional. Revista Eletrônica de Ciência Administrativa, v. 16, n. 2, p. 127-150, 2017.

SANTOS, F. N. D.; FEITOSA, A. P. C. C. Festejo junino em Miguel Calmon-Bahia: estudo do potencial turístico-cultural para o município. Revista Acadêmica do Observatório de Inovação do Turismo, v. 9, n. 1, p. 122-147, 2015. 
SEBRAE (Serviço Brasileiro de Apoio às Micro e Pequenas Empresas). Relatório dos empresários da indústria, construção, comércio e serviços no Brasil de 2002 a 2012, 2015.

SILVA, A. B. A vivência de conflitos entre a prática gerencial e as relações em família. 2005. Tese (Doutorado em Engenharia de Produção). - Universidade Federal de Santa Catarina, Florianópolis, 2005

SILVA, I. C.; SILVA, K. A. T.; FREITAS, R. C. Ensino de Administração: Reflexões Críticas sobre a Formação do Administrador. IV EnEPQ. Brasília/DF, 2013.

VALE, C. A. R., BARBOSA, F. P., \& CARVALHO, A. M. R. Cordel, uma história de gerações.

Revista Interdisciplinar de Gestão Social, v. 2, n. 2, p. 83-84, 2013.

ZABALZA, M. A. O ensino universitário: seu cenário e seus protagonistas. Porto Alegre: Artmed, 2004. 